\title{
Chemistry for Beginners: What Makes Good and Bad Impression
}

\author{
Inas Sausan, Sulistyo Saputro, Nurma Yunita Indriyanti \\ Master of Chemistry Education, Postgraduate Program, Sebelas Maret University \\ Surakarta, Indonesia \\ *inassausan22@student.uns.ac.id
}

\begin{abstract}
Most secondary high school students think that chemistry was a difficult subject. Bad perception can influence the students' interest in chemistry. We aimed was to explore the students' perception toward chemistry in junior high school and its influences on students' interest to learn chemistry in secondary school. The qualitative-descriptive as the research method. The data were collected using several techniques: interview, classroom observation, and questionnaires. One science teacher and 27 junior high school students participated in this research. The results showed the junior high school students' interested with experimentation activities in learning chemistry, but they considered the chemistry as a complex science lesson with abstract symbols and terms must be memorized. The teachers' skill to deliver the abstract concept influences the students' interest. Bad perception toward chemistry makes students not interested in learning chemistry in secondary high school because they do not feel curious. Therefore, teachers are suggested to create a good first impression in learning chemistry.
\end{abstract}

Keywords-Chemistry; junior high school; perception

\section{INTRODUCTION}

According to the curriculum of science teaching, there are several science lessons taught in secondary school. One of them was chemistry. Chemistry is an important subject, it discusses the composition and structure of things around us. Yet, chemistry often described as an unpopular subject among the students [1]. Most of students in secondary school think that chemistry was difficult [2], [3], it is also not interesting and important [4]. Several researches have shown the source of students' difficulties to learn chemistry was the abstract concepts of chemistry [5], inappropriate and irrelevant instructions with the real world situations [6], and chemistry is supposed to have difficult scientific terminology [7].

The difficulty of learning chemistry makes students have low positive perception on chemistry [8]. The study showed the students have the low level of interest and motivation in learning science because they have less knowledge about the relevance of learning about science to their life [9]. Students' perception influences their interest, the way they treat to subject and their expectations. Bad perception can influence the students' approaches toward their subject. The students' perceptions were linked closely with their expectations [10] about their engagement with their learning in favor of deep approaches to learning. Other research concluded how students interprete and experience courses were important [11]. If the students consider the learning in the class was badly implemented, overloaded with homework, and no relevance with their life, they will just to approach it in the surface rather than in the deep of the content.

The first students' impression can influence their interpretation of the future event, they consistently memorize the information of their first believes [12]. Chemistry is first introduced and taught to students in junior high school. In seventh grade, students learn about the classification of matter and its changes. In this chapter, students were introduced to several new chemical terms, the element symbols, and visualization of atoms and molecules. Johnstone [13] stated, there were three levels of science considered as one of the concepts mapping of the closed-cluster chemistry which is centrally important. They were related to and support each other. Chemistry has an approach to building students' idea through material building [14].

This research was conducted as the first investigation toward the junior high school students' perceptions. The better understanding of students' perception toward chemistry learning enables teachers to design class activities and learning strategies which promotes a meaningful learning. This research was aimed to investigate; 1) the junior high school students' perception toward chemistry; 2) its influences on students' interest to learn chemistry in secondary school.

\section{METHOD}

The qualitative-descriptive research design was used to investigate the students' perception and its influences on chemistry learning. This research was the collaboration between science teacher and 27 students from the junior high school in the District of Wonopringgo, Pekalongan City, Indonesia. The participants were selected using purposive sampling. They come from a private, nonprofit school with heterogeneous student populations. The students from this school were selected as the representatives of those surveyed in the purposive sampling process. The selection criteria considered including junior high school who gets the first chemistry learning. Data were collected by the interview, classroom observation, and questionnaires. The questionnaire was referred to the three basic elements of 
perceptions [15]. The questionnaire was presented with 18 semiclosed questions to determine the students' perception. The questionnaire consisted of two options (yes or no) which were explained with answers. A semi-structured interview was conducted to explore the information from each dimension of perception characteristic. Students were also asked about their thought and interest toward chemistry in the future.

\section{RESULT AND DISCUSSION}

Perception was "the process of collecting information about the world through the senses" [16]. There were three elements of perception [15]. First, the perceiver was the one who was experiencing; second, the target, something to be perceived; and third, situation context where the objects exist. In this research, the students were the subject of perception that collects the information about chemistry as the target measured with the dimension of three perception elements.

Figure 1 showed the result of positive-negative students' perception toward chemistry. Meanwhile, students' perception toward chemistry was explored by the questionnaire and interviews are shown in Table 1.

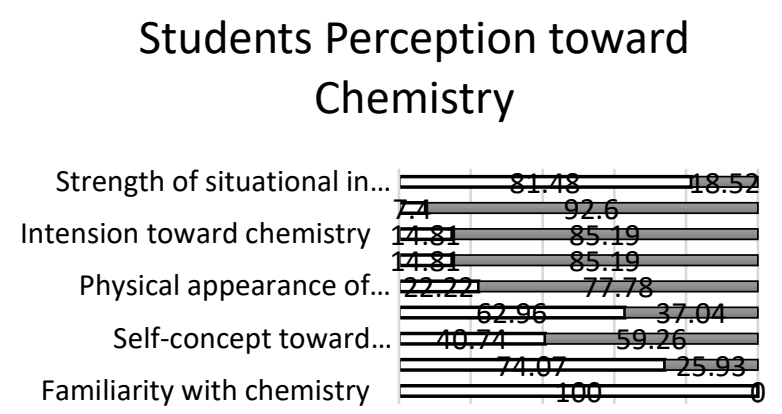

$\begin{array}{llllll}0 \% & 20 \% & 40 \% & 60 \% & 80 \% & 100 \%\end{array}$

\section{$\square$ Positive $\square$ Negative}

Figure. 1: Percentage of students' positive-negative perception toward Chemistry

The students have positive and negative perceptions toward Chemistry based on their view. Most of them criticize the characteristic of Chemistry, teachers' skill, and learning environment. In Figure 1, we know all students have recognized Chemistry. They familiar with the "Chemistry term" from their former teachers and seniors who have studied the material. However, in Table 1 showed the students only know about "chemical terms" in general science education. Several students think the "cell and human body" belongs to the chapter in chemistry. The students expressed their own idea, but they use the structure of causality discourse even though the content of the reason was from their naive or intuitive theories [17], [18]. They have not been able to differentiated the content of biology, physic, and chemistry. It was because product impact from integrated science subject in junior high school.

The dimension of the mood about chemistry has positive perception because students considered the chemistry has many experimental activities such as mixing the solution in the laboratory. The experimental class became the most-waited class for the students. Students were enthusiastic about several practical and direct experiences. Many students stated that "science is magic." They were more conscious about experiment related to "the laboratory" [17].

The result of the interview showed that the students think chemistry was not relevant and no benefits to solve real-life problems. One of the causes of this misunderstanding was the less contextual explanation from the teacher. Contextual learning provided learning by connecting academic content to the real-life situations helps the student to store long-term memory which will help them later in their life. Students attempted to understand the world around them since they were little, and unconsciously use the empirical and informal basic activities when they start to give the reason. Through the repetition of this activity, they create their initial intuitive theory [17].

\section{TABLE I. STUDENTS' PERCEPTION TOWARD CHEMISTRY}

\begin{tabular}{|c|c|c|}
\hline $\begin{array}{c}\text { Characteristic of } \\
\text { perceptions }\end{array}$ & Dimensions & Result \\
\hline \multirow[t]{4}{*}{$\begin{array}{l}\text { The perceiver's } \\
\text { specific } \\
\text { characteristic }\end{array}$} & $\begin{array}{c}\text { Familiarity } \\
\text { with Chemistry }\end{array}$ & $\begin{array}{l}\text { Students only recognized the } \\
\text { "chemistry term" without } \\
\text { knowing the content. }\end{array}$ \\
\hline & Mood & $\begin{array}{c}\text { Students interested with the } \\
\text { experimental activity in the } \\
\text { class. }\end{array}$ \\
\hline & Self-concept & $\begin{array}{l}\text { Students considered learning } \\
\text { chemistry has no benefits in } \\
\text { their life. }\end{array}$ \\
\hline & $\begin{array}{l}\text { Cognitive } \\
\text { structure }\end{array}$ & $\begin{array}{l}\text { Students didn't believe the } \\
\text { unfamiliar information about } \\
\text { chemistry which is illogical and } \\
\text { inappropriate with their } \\
\text { previous knowledge. }\end{array}$ \\
\hline \multirow[t]{3}{*}{$\begin{array}{l}\text { Target's specific } \\
\text { characteristics }\end{array}$} & $\begin{array}{c}\text { Physical } \\
\text { appearance }\end{array}$ & $\begin{array}{l}\text { Chemistry is a complex subject } \\
\text { contains inconsistent symbols. }\end{array}$ \\
\hline & $\begin{array}{l}\text { Verbal/nonverb } \\
\text { al }\end{array}$ & $\begin{array}{l}\text { Several terms must be } \\
\text { memorized in which the terms } \\
\text { are the illogical abstract } \\
\text { concept. }\end{array}$ \\
\hline & Intention & $\begin{array}{l}\text { Only students with high } \\
\text { mathematical skill can } \\
\text { understand chemistry. }\end{array}$ \\
\hline \multirow[t]{2}{*}{$\begin{array}{l}\text { Situation's } \\
\text { specific } \\
\text { characteristics }\end{array}$} & Social context & $\begin{array}{l}\text { The teachers' skill in delivering } \\
\text { the abstract concept could cause } \\
\text { disinterest to learn chemistry. } \\
\text { Teachers didn't implement the } \\
\text { three levels of learning in } \\
\text { chemistry. }\end{array}$ \\
\hline & $\begin{array}{l}\text { Strength of } \\
\text { situational } \\
\text { context }\end{array}$ & $\begin{array}{l}\text { The use of integrated media in } \\
\text { learning chemistry can help } \\
\text { students in visualizing the } \\
\text { subjects of chemistry. }\end{array}$ \\
\hline
\end{tabular}

The information from outside will be processed and matched to the students' preconception. They will select the facts which were appropriate to their previous knowledge and cast off the inappropriate one. It must be plausible in the students' conceptual system in the explanation of "conceptual systems" [19]. The stereotype of chemistry as a difficult subject has been stuck in students' mind. Chemical symbols that usually change becomes one of the stereotype reasons believed by students. The 
stereotype was a scheme taken too far because they reduced and ignored the one's individuality and diversity in a bigger group. The stereotype was usually caused by the lack of information about the target [20].

Many symbols and terms in chemistry make students attempted to memorize without understanding the meaning. In the theory of education and practice, the key of subject translation was to use the language, terms, and collection of vocabularies of the subject [21]. Verbal/nonverbal dimensions of chemistry related to the terms and languages in chemistry provides the most negative perception among the other dimensions. Students found difficulties to describe abstract things and molecules types in the classification of matter and its changes. Chemistry commonly incorporates many abstract concepts, which are important because further chemistry cannot be easily understood if these underpinning concepts are not mastered by the students. The interplay between the macroscopic and submicroscopic levels of thought was the essential characteristics of chemistry and it was a source of difficulty for many chemistry learners [22]. The teachers' skill to explained the abstract things by representing and visualizing it can be significantly accepted and created the students' positive perception toward chemistry. Integrating three levels of learning chemistry must be implemented in the learning activity [13]. It is expected the students can recognized the meaning of the terms, and the explanation between symbols and submicroscopic levels.

Based on the number of positive-negative perception on chemistry and its reasons of selection, the junior high school students have the low positive perception on chemistrydimiti. It caused by the characteristic of chemistry, students' views, and situations in the class. The low positive perception can affect students' interest to learn chemistry in the future because their curiosity to learn chemistry did not appear. The curiosity was important to push students to explore more [23] about chemistry. Students will consider whether they will learn chemistry in secondary high school based on their initial perception in junior high school. The previous research showed the students would involve in learning and choosing science in senior high school if they have interest in the topic [24], engaged in their studies and have developed networks with their fellow students [10]. Being aware of students' perceptions toward chemistry could be crucial because the teacher can prepare with the learning strategy to support students with their studies. The teachers' attempt was to design the attractive learning by conducting experimental activity in the class. Building a good impression will give positive effect to the students' interest in the future. The previous research has shown that nonverbal attitude which was relatively related to the formation of the first impression is stable enough in several learning activities [21]. The first impression might be predictive because students tend to become a valid indicator of instruction quality.

\section{CONCLUSION}

From the results it can be concluded the junior high school students familiar with chemistry from their teacher's and senior's but they did not able yet to distinguish content between chemistry, physics, and biology. The students interested in experimental activities such as mixing solution because it is joyful learning. Based on the characteristic of chemistry, students considered chemistry was a complex science with symbols and terms that should be memorized without understanding the meaning. Many students seems difficult to think of abstract concepts in learning chemistry but actually, these abstract concepts were important because further chemistry cannot be easily understood if these underpinning concepts were not mastered. Bad perceptions toward chemistry made the students did not interested to learn chemistry in high school because their curiosity did not appeared. Thus, it is recommended to make a good first impression about chemistry learning in the junior high school. The students who have a good first impression toward chemistry will considered chemistry as an interesting science subject.

\section{REFERENCES}

[1] A. Hofstein, I. Eilks, and R. Bybee, "Societal Issues and Their Importance for Contemporary Science Education--A Pedagogical Justification and the State-of-the-Art in Israel, Germany, and the USA", Int. J. Sci. Math. Educ, vol. 9, pp 1459-83, 2011

[2] T. Ali, "A Case Study of the Common Difficulties Experienced by High School Students in Chemistry Classroom in Gilgit-Baltistan (Pakistan)", SAGE Open, vol. 2, pp 1-13, 2012

[3] C. S. Carter and N. W. Brickhouse, "What makes chemistry difficult? Alternate perceptions", J. Chem. Educ, vol. 66, p 233, 1989

[4] K. Broman, M. Ekborg, and D. Johnels, "Chemistry in crisis? Perspectives on teaching and learning chemistry in Swedish upper secondary schools", NORDINA, vol. 7, pp 43-60, 2011

[5] M. B. Nakhleh, "Why some Students don't Learn Chemistry" J. Chem. Educ. Vol. 69, p 191, 1992

[6] G. Aikenhead, "Chemistry and physics instruction: integration, ideologies, and choices", Chem. Educ. Res. Pract, vol. 4, no. 11, pp 5-30, 2003

[7] M. M. Woldeamanuel, H. Atagana, and T. Engida, "What Makes Chemistry Difficult?”, African J. Chem. Educ, vol. 4, pp 31-4, 2014

[8] M. Kubiatko, Eurasia J. Math. Sci. Tech. Ed, vol. 11 no. 8, pp 55-63, 2015

[9] E. W. Jenkins and N. W. Nelson, "Important but not for me: students' attitudes towards secondary school science in England", Res. Sci. Technol. Educ. vol. 23, pp 41-57, 2005

[10] J. Tudor, R. Penlington, and L. Mcdowell, "Perceptions and their influences on approaches to learning”, Eng. Educ. vol. 5, pp 69-79, 2010

[11] R. A. Ellis, P. Goodyear, R. A. Calvo, and M. Prosser, "Engineering students' conceptions of and approaches to learning through discussions in face-to-face and online contexts", Learn. Instr. Vol. 18, pp 267-82, 2008

[12] M. Rabin and J. L. Schrag, "First Impressions Matter: A Model of Confirmatory Bias", The Quarterly J. Econ, vol. 114 pp 37-82, 1999

[13] A. H. Johnstone, J. Comput Assist Learn, vol. 7, pp 75-83, 1991

[14] [14] Merritt J, Krajcik J S, and Shwartz Y 2008 Development of a learning progression for the particle model of matter Proc. 8th Int. Conf. Learn. Sci. 2 75-81

[15] [15] Nelson D I and Quick J C 1997 Organization Behavior: Foundation, Realities, and Challenges New York West Publishing Company 83-4

[16] [16] Lewis A 2001 Educare 30 272-88

[17] [17] Naude F 2015 SAJCE 5 1-9

[18] [18] Pine K, Messer D, and John K S 2001 Research in Science \& Technological Education 19 79-96

[19] [19] Lakoff G 1991 Lang. Commun.11 53-62

[20] M. Guyll, S. Madon, L. Prieto, and K. C. Scherr, J. Soc, vol. 66, pp 113 30,2010

[21] M. Weisbuch, M. L. Slepian, A. Clarke, N. Ambady, and J. VeenstraVanderWeele, "Behavioral Stability Across Time and Situations: Nonverbal Versus Verbal Consistency", J. Nonverbal Behav, vol. 34, pp 43-56, 2010 
[22] G. Sirhan, J. Turkish Sci. Educ, vol. 4, pp 2-20, 2007

[23] D. Pathak, P. Agrawal, A. A. Efros, and T. Darrell , "Curiosity-driven Exploration by Self-supervised Prediction", 26-27 July IEEE Conf. CVPRW, pp 488-9, 2017
[24] J. Osborne, S. Simon, and S. Collins, "Attitudes towards science: A review of the literature and its implications”, Int. J. Sci. Educ. vol. 25, pp 1049-79, 2003 